\title{
CORE INTENTIONAL FEATURES IN THE SYNTACTIC COMPUTATION: DERIVING THE POSITION OF THE SUBJECT IN SPANISH
}

\author{
Ana Ojea (Universidad de Oviedo) \\ Forthcoming in Lingua
}

\begin{abstract}
This work introduces a subset of informational features (termed core intentional features), different from standard pragmatic features such as topic and focus. Adopting the basic tenets of the Minimalist program, core intentional features are defined as edge features which sit in the relevant phases and are subject to parametric variation. They are assumed to drive the derivation of the sentence so that it constitutes an intentionally-adequate object (i.e. a categorical or a thetic statement) even in the absence of a particular communicative situation.

The paper specifically focuses on one of these features, [DI] (discourse intention), and on how it determines the eventual position of the subject in a discourse-prominent language such as Spanish. A preliminary distinction is made between sentences that inaugurate the discourse (dsentences) and sentences which are integrated in a particular context (context-dependent sentences). It is argued that the SV/VS order in Spanish follows from the conditions of valuation of $[\mathrm{DI}]$ in each case; in particular, valuation of $[\mathrm{DI}]$ in $\mathrm{d}$-sentences will be a matter of structural and semantic prominence whereas in context-dependent sentences it will depend on pragmatic conditions. The paper also addresses a number of significant contrasts in the muchdebated issue of the placement of the subject in Spanish, which receive a principled explanation under the theory of core intentional features proposed here.
\end{abstract}

Keywords: Core intentional features; discourse intention; categorical/thetic statements; Spanish syntax; subject position; grammatical prominence

\section{Introduction}

Linguistic studies, in both the functional and the formal paradigm, have devoted much effort to discussing the role that discourse-related features like topic and focus play in determining the truth conditions of a sentence and its phonological and structural 
properties. These discourse features are essentially related to what is taken to be old and new information in the sentence and have customarily been defined referentially, that is, in relation to the encyclopedic knowledge of the speaker-hearer or to a given linguistic context. As an example of the latter case consider the following conversational exchanges, which show how a particular communicative situation conditions what is understood as old (topical) or new (focal) information: ${ }^{1}$

(1) a. A/ Who has John promoted for that post? B/ John has promoted PETER.

b. A/ Who has promoted Peter for that post? B/ JOHN has promoted Peter.

c. A/ What has happened? B/ JOHN HAS PROMOTED PETER FOR THAT POST.

In B response to the question in (1a), John will be the topic of the sentence (i.e. the category, previously activated by the discourse, which signals what the sentence is about), and Peter the focus (i.e. the category that provides a resolution for the variable left open in the previous discourse). In (1b), on the contrary, John, in the same structural position (but phonologically accented), will be the focus and Peter the topic. Finally, in $B$ response in (1c), the whole sentence is said to constitute new information (i.e. an allfocus sentence).

Note, however, that a linguistic object like John has promoted Peter for that post may inaugurate the discourse or even constitute an independent discourse in itself, regardless of any presupposed context. In the absence of some previous background information, what counts as old and new information will be defined relationally (i.e. sentence internally), in terms of what is taken to be the point of departure of the proposition (John) and what is its informational focus (has promoted Peter). ${ }^{2}$ As native speakers of a language we can discriminate which sentences are intentionally independent (John has promoted Peter for that post) and which sentences require a context to be intentionally adequate (Peter, John has promoted for that post). This is then part of our linguistic competence.

1 As repeatedly noticed, informational concepts have been surrounded by a great deal of terminological indefinition, to the point that one can find not only different terms for the same notion but also contradictory accounts of what they imply (cf. Breul, 2004; Casielles, 2004; Gundel and Fretheim, 2005; Gupton 2010; López 2009; Reinhart, 1981; Vallduví, 1992, among others, and references therein).

\footnotetext{
${ }^{2}$ Under this relational approach, $\mathrm{X}(\mathrm{John})$ is old information in relation to $\mathrm{Y}$ (has promoted Peter) in the sense that $\mathrm{X}$ is outside the scope of what is predicated in $\mathrm{Y}$. And $\mathrm{Y}$ is new in relation to $\mathrm{X}$ in the sense that it is the information asserted about $\mathrm{X}$ (cf. Gundel and Fretheim, 2005: 176).
} 
With this in mind, I will contend here that information structure comprises two different types of features:

a) pragmatic features: features like [topic] and [focus], which are context dependent and, as such, strictly associated to particular communicative situations; they serve to codify what is old and new information referentially.

b) what I term core intentional features, context independent features which are present in all sentences, that is, not only in those which are integrated in a particular communicative situation but also in those which codify what is old and new relationally, i.e. regardless of a particular speaker-hearer exchange situation.

Assuming the basic tenets of the Minimalist approach (cf. Chomsky 1995 and subsequent work), in section 2 I will argue that these are edge features which sit in the relevant phases and are subject to parametric variation; their role in the derivation will then be totally equivalent to that of formal features like Agree or Case, and expectedly their valuation will be regulated by the computational mechanism under strict conditions of prominence. I will test the empirical validity of this proposal in section 3 , where I will show how one core intentional feature (which I will label [DI]) determines the canonical word order in Spanish, in particular the position of the subject with respect to the verb. Section 4 offers some conclusions.

\section{Core intentional features}

One of the basic assumptions of the Minimalist program is that languages incorporate mechanisms that determine an infinite array of hierarchically structured expressions which are transferred for interpretation to two interfaces: the sensory-motor system and the conceptual-intentional system. Central to this mechanism is the operation Merge, which constructs syntactic objects by combining lexical elements under selection restrictions (External Merge) or yields displacements through the merging of a constituent to an already existing syntactic object (Internal Merge). All Merge operations are driven by edge features (EFs). EFs are present on all nodes and must be satisfied at least once by way of some variety of Merge for a derivation to be convergent. In Chomsky's (2008) system, the fundamental difference between External Merge and Internal Merge reduces to a difference between phase heads and non-phase heads with regard to EFs. In short, EFs on non-phase heads drive External Merge, while 
EFs on phase heads drive Internal Merge (i.e. movement). ${ }^{3}$ Phases are $\mathrm{CP}$ and $\mathrm{v}^{*} \mathrm{P}$, where CP is shorthand for the region that Rizzi (1997) calls the "left periphery," and v* is the functional head associated with full argument structure. TP is not a phase in this system but it inherits EF features from a higher phase head (i.e. from $\mathrm{C}$ ), thus becoming a probe for Internal Movement. ${ }^{4}$ Note, incidentally, that EF features in $\mathrm{CP}$ and $\mathrm{v} * \mathrm{P}$ were initially labelled EPP features (cf. Chomsky 2000: 102), and therefore these two terms have been sometimes used indistinctively in the literature. Nevertheless, given the original conception of the EPP (Extended Projection Principle) as a specific principle of well-formedness which forces all clauses to have a subject, most authors restrict the term EPP to the EF inherited by T. It is in this restricted sense that the term will be used in this paper (see Villa García, forthcoming, for an overview of the EPP and its relevance in the syntax of Spanish).

Derivations proceed cyclically, that is, at various stages of the computation there are transfers to the two interfaces and the phases will have to make a contribution to them. For the conceptual-intentional system this means that they must make a contribution to the LF (i.e. all uninterpretable features must have been valued) and must also be intentionally adequate, which implies being discourse-legible.

The null hypothesis in this respect is that sentences must be intentionally adequate even when they are not integrated in a particular communicative situation, that is, even if considered in isolation. I will term those sentences which inaugurate the discourse and may constitute independent discourses in themselves $d$-sentences. Significantly, dsentences display the unmarked order of constituents and therefore constitute the best scenario to explore which aspects of the unmarked order of a language follow from strict grammatical conditions and which from output/interface considerations (i.e. the

\footnotetext{
${ }^{3}$ Chomsky (2008: 298) established a correlation between IM and discourse-related properties: "[t]o a large extent, EM yields generalized argument structure (theta roles, the "cartographic" hierarchies, and similar properties); and IM yields discourse-related properties such as old information and specificity, along with scopal effects". The proposal I sustain below is consistent with this view of the informational import of Internal Merge.

${ }^{4}$ Here I adopt the static approach to phases in Chomsky (2008). As noted by an anonymous reviewer, a number of recent works assume a more dynamic approach where the phasal status of a phrase can be affected by the syntactic context in which it occurs (see, among others, Bobaljik and Wurmbrand, 2005; Bošković, 2016 and Gallego 2007). The proposal I make in this paper can be easily accommodated in models of this sort provided the phasal status of TP is ensured.
} 
need for the linguistic object to be intentionally legible). ${ }^{5}$ Consider in this respect the case of Spanish, to which I will return in more detail latter:

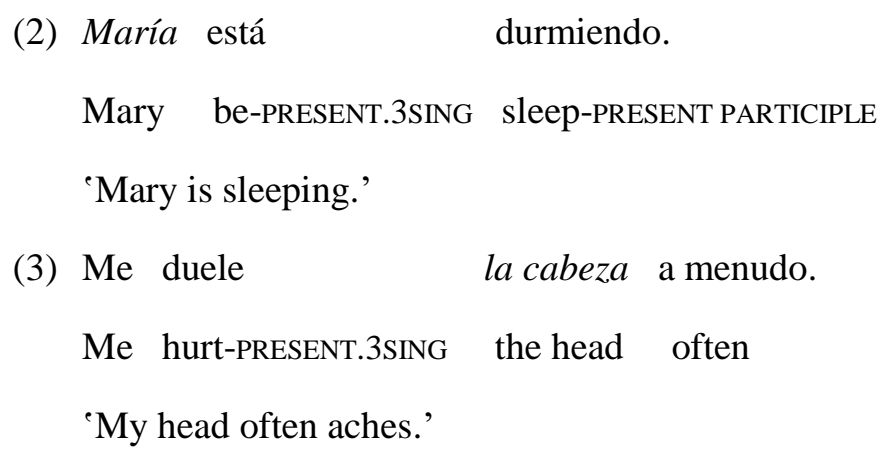

The subject (María and la cabeza in the examples above) must be preverbal in (2) but postverbal in (3). ${ }^{6}$ The fact that the d-sentence (3) is structurally well-formed implies that Case and agreement requirements in Spanish can be satisfied VP internally, which in turn means that the rising of the subject to Spec,TP in (2) must have been motivated for reasons other than the need to value some formal feature, as would be the case in languages like English. There is also general consensus that preverbal subjects like those in (2) have informational import, and this implies that subject raising in Spanish is forced by some informational feature which is context-independent and therefore present in the derivation of all sentences, including $d$-sentences. Note that if the subject does not raise in (2), or if it does in (3), the derivation, though convergent, will not be legible to the C-I system unless the sentence is associated to a particular context: ${ }^{7}$

5 What I term here $d$-sentences are by definition "out-of-the-blue sentences". I have consciously avoided this term because out-of-the-blue sentences (the "neutral descriptions" for Kuno, 1972) have customarily been equated with all-focus (thetic) utterances. Note, however that this equation follows from an informational partition of sentences which is contextual (i.e. referential) in nature, as in (1c); if considered in isolation, though, an out-of-the-blue sentence needs not be all-focus since it may serve to name an entity and predicate something about it, i.e. it may constitute a categorical statement (cf. Meinunger 2000:46; Breul 2004: 65).

${ }^{6}$ I use the term subject with no further specification to refer to the DP which displays some morphological agreement with the inflected verb. Significantly, in Spanish, contrary to what happens for example in English, the subject thus understood does not always coincide with the structural subject (i.e. the category which sits in Spec,TP) and therefore does not always appear in a preverbal position in dsentences. It does not need to be the logical/notional subject either, that is, it does not necessarily mark the given information of the sentence in the relational sense above (see section 3 ).

${ }^{7}$ In what follows I will mark with [c] those sentences which are context-dependent, i.e. intentionally adequate only in particular communicative situations. The sentence in (4) will be possible in a narrow 
(4) Está

durmiendo

María. [c]

Be-PRESENT.3SING sleep-PRESENT PARTICIPLE Mary

'Mary is sleeping.'

(5) La cabeza me está doliendo. [c]

The head me be-PRESENT.3SING hurt-PRESENT PARTICIPLE

'My head is aching.'

Therefore, some informational features must have the same status in the derivation than formal or semantic features, all of them co-operating to obtain a fully convergent (structurally, semantically and intentionally) object. I would then like to entertain the idea that information structure (IS) comprises two types of features: core intentional features and pragmatic features:

(6) Types of features in the derivation

Semantic/conceptual features

Formal features

Context independent

Informational features $\quad\left[\begin{array}{l}\text { Core intentional } \\ \text { Pragmatic }\end{array}\right]$ Context dependent

Pragmatic features are optional features present on certain lexical projections when the sentence is in context; these features are then context-dependent and codify notions like Aboutness-shift Topics, Familiar Topics, and Contrastive Topics in the topic sphere (cf. Frascarelli and Hinterhölzl, 2007); ${ }^{8}$ or Contrastive Focus, Mirative Focus (cf. Cruschina, 2012), Resumptive Preposing (cf. Cinque, 1990; Leonetti and Escandell, 2009), and Quantifier fronting/Negative Preposing (cf. Bosque, 1980; Âmbar, 1999; Barbosa, 2001; Quer, 2002), in the focus sphere. ${ }^{9}$

As opposed to them, core intentional features are obligatory EFs which sit on the relevant phases; they drive the derivation so that a sentence constitutes an adequate discourse and thus a legible object at the interfaces even when it is not inserted in a

focus context (as an answer to the question ¿Quién está durmiendo en esa habitación? 'Who is sleeping in that room'), whereas (5) generally requires a contrastive reading (see below).

${ }^{8}$ See Büring (1999) or Gundel (1999) for an alternative classification of topics.

${ }^{9}$ See Jiménez-Fernández (2015) for a typology of focus in the generative framework. 
context. When the derivation consists of only semantic, formal and core intentional features a d-sentence will be obtained (i.e. a canonical sentence in the standard sense).

Expectedly there must be (at least) one core intentional feature in each relevant phase: one in $\mathrm{C}$ (which I will call [DI]: discourse intention), to mark the point of departure of the proposition, and one in $\mathrm{V}^{*} \mathrm{P}$ to mark its informational focus [IF].$^{10} \mathrm{I}$ take the term informational focus from Kiss (1998: 246), where it is defined as "the nonpresupposed information marked by one or more pitch accents -without expressing exhaustive identification performed on a set of contextually or situationally given entities". The informational focus then constitutes the informative part of the sentence and in d-sentences it is unmarkedly sentence-final. Contrary to other types of (optional) pragmatic foci, the informational focus is an essential part in the information processing of the sentence and has truth conditional effects (see section 3, with some crashing derivations resulting from the lack of an informational focus in the sentence).

Both $[\mathrm{DI}]$ and $[\mathrm{IF}]$ are truth-conditionally relevant and contribute to the logicalsemantic interpretation of the sentence (vid. Strawson, 1964; Reinhart, 1981; Gundel and Freitheim, 2005 among others). In this paper, I will focus on [DI] and on the role it has in the derivation. I assume that it determines the point of departure of the sentence so that a double/single judgement obtains, that is, it organizes the information structure to make it fit one of the two points of view from which a state of affairs can necessarily be regarded: ${ }^{11}$

a) as a categorical statement (i.e. a logical bipartite structure), where an entity is named and something is predicated about it

b) as an event-reporting thetic statement (i.e. a single logically-unstructured complex), which merely expresses a state of affairs located in some spatio-temporal coordinates

\footnotetext{
${ }^{10}$ Chomsky (2008) suggests that DP too may be a phase, given its similarities with CP. In this case, there should be some core intentional feature in DP as well, and, if the ideas in this paper are on the right track, this feature could have structural effects in some languages. I leave this issue open for further research.

${ }^{11}$ I adhere here to the tradition which started with the philosophers Brentano and Marty in the $19^{\text {th }}$ century and gained syntactic relevance after the work of Kuroda (1972) (see Breul, 2004; Ladusaw, 2000 and Sasse, 1987 for references and discussion).
} 
Accordingly, the category that holds [DI] must probe either a constituent that names an entity or a constituent that frames the event in place or time. I will call the constituent that finally values [DI] the intentional base of the sentence. Therefore,

a) if the intentional base is a nominal category, a categorical statement will follow, where the nominal category is the logical subject of the predication and the rest of the proposition is the logical predicate. The category that serves as a goal for [DI] must represent an existing reference (i.e. denote an individual or a set) since it constitutes the base of the predication. ${ }^{12}$

b) if the intentional base is a locative category, the sentence will be conceived as simply asserting the existence of the event: a thetic statement, all-new in the relational sense above.

In the absence of a context (i.e. in d-sentences), the prediction is that the selection of the intentional base to value [DI] will be regulated by the computational mechanism, only attending to the particular output of external merge. In particular I propose that in d-sentences the category hosting [DI] must probe a nominal or a locative constituent under conditions of structural and semantic prominence. In other words, which constituent will eventually be targeted to be the intentional base (and, accordingly, the intentional status of the sentence as a categorical or thetic statement) will depend on sentence-internal conditions of prominence. ${ }^{13}$ The constituent will have to be structurally prominent, that is, in a local relation to the probe. It will also have to be semantically prominent, representing an existing reference (an individual or a set in the case of categorical statements, or some locative frame in thetic statements). Valuation of

12 The requirement for the constituent which values [DI] to be referential in categorical statements follows from the presuppositional nature of the intentional base in this type of judgements: only if its reference is presupposed will it be possible to attribute some property to it.

13 The constituent eventually targeted to value [DI] will gain informational prominence (i.e. will serve to organize the information structure of the sentence) and structural prominence (i.e. will be placed sentence-initially in some languages); therefore, it makes sense to assume that it must be grammatically prominent to serve as an adequate goal (see Gutiérrez Bravo, 2007 for a proposal to explain the unmarked structural order in Spanish which bases on prominence scales. Though sharing this leading intuition, our analyses differ significantly). 
[DI] in d-sentences will thus be a matter of computational efficiency, an optimal way to link the structure obtained after E-merge with the intentional module: ${ }^{14}$

(7) Valuation of [DI] in d-sentences

The category hosting [DI] probes a nominal or a locative constituent under conditions of semantic and structural prominence

On the contrary, when the sentence is integrated in a particular communicative situation, valuation of [DI] will be a matter of pragmatics (see 3.2).

Finally, as a core intentional feature, [DI] is part of the inventory of UG and subject to parametric variation. I will adopt here the classification defended in JiménezFernández and Miyagawa (2014), according to which languages can be classified as: ${ }^{15}$

(8) A/ Agreement prominent: the agreement features of $\mathrm{C}$ are inherited by $\mathrm{T}$

$\mathrm{B}$ / Discourse prominent: the core intentional feature(s) in $\mathrm{C}$ are inherited by $\mathrm{T}$

Whereas in type-A languages, such as English, the core intentional feature [DI] remains in $\mathrm{C}$ and will only be accessed at the interfaces, in type- $\mathrm{B}$ languages, such as Spanish, [DI] will be inherited by $\mathrm{T}$, which then becomes a probe in search of an adequate goal to be internally merged in T (i.e. [DI] produces effects on the narrow syntax). Analyzing the role of the feature [DI] in the d-sentences of a discourseprominent language will then be a good means to detect which aspects of the canonical structure of that language follow from the need for the linguistic object to be intentionally adequate and which from other grammatical constraints.

14 As argued above, core intentional features have the same status in the derivation than formal features and therefore movement induced by [DI] displays the properties of formal feature-driven movements, namely: (a) it is obligatory and (b) it has a fixed landing site in the structure: the Spec position of the functional head where it projects (cf. Horvath, 2008). Note, though, that [DI] does not rely on Agree for its licensing but on structural prominence and, given that competition in prominence results in intervention problems, its valuation is subject to stricter locality requirements than those behind valuation of phi-features.

15 Jiménez-Fernández and Miyagawa (2014) do not distinguish between core intentional features and pragmatic features, a point to which I will return later. Given the parametric options in (7), the implication that follows is that in an agreement-prominent language such as English, the core intentional feature [DI] will only be accessed at the interfaces, in particular at the PF-component. Therefore the distinction between a categorical and a thetic d-sentence in English will be phonological: in categorical statements both the subject and the predicate receive high pitch, whereas in thetic statements only the subject does (cf. Sasse, 1987: 519-526). 
To show this, I will discuss here how the conditions in (7) determine the distribution of the subject in Spanish d-sentences, which, as is well known, must be preverbal in some cases (9) but obligatorily (10) or optionally (11) postverbal in others: ${ }^{16}$

(9) Juan está escribiendo una novela.

John be-PRESENT.3SING write-PRESENT PARTICIPLE a novel

'John is writing a novel.'

(10) A Juan le preocupa tu salud.

At John him worry-PRESENT.3SING your health

'Your health worries John.'

(11)a. El tren nocturno ha llegado a la estación central.

The train nocturnal have-PRESENT.3SING arrive-PAST PARTICIPLE at the station central

b. Ha llegado el tren nocturno a la estación central.

Have-PRESENT.3SING arrive-PAST PARTICIPLE the train nocturnal at the station central

'The night train has arrived at central station.'

In the next section I will provide a principled explanation of these facts. I will focus on the position of the subject in d-sentences and then sketch some tentative proposal to explain the more flexible orderings in context-dependent sentences.

\section{Deriving the position of the subject in Spanish}

The conditions of valuation of [DI] in (7) predict that the semantic prominence of the DP subject and its structural position in the VP after external merge will be crucial to determine its final position in a d-sentence. Therefore the conceptual structure of the predicate will drastically condition the options here and, as a consequence, the reading of the sentence as a categorical or thetic statement. For obvious reasons, options will be more varied in the case of context-dependent sentences.

3.1. The position of the subject in Spanish d-sentences.

\footnotetext{
${ }^{16}$ Postverbal subjects in d-sentences as (10) or (11) are clearly different from the postverbal subjects which appear in the narrow focus in context annotated sentences (¿Quién está escribiendo una novela? 'Who is writing a novel?' Está escribiendo una novela Juan 'JOHN is writing a novel'). For a description of the different contexts in which postverbal subjects are possible in Spanish see Villa-García (forthcoming); for an explicit analysis of those which are focal, see, among others, Ortega-Santos (2016).
} 
The derivation of a d-sentence in Spanish roughly proceeds as follows. The verb enters the Numeration inflected for person/number agreement features and also for tense and grammatical aspect (the 'situation-external' and the 'situation-internal' time of Comrie, 1976); this means that verbal morphology in Spanish may serve to locate a particular interval of the event in the speech time. As standardly assumed, perfective forms (canto/ha cantado) focus the temporal bounds of the predicate, and progressive forms (estálestaba/estuvo cantando) mark its middle time (cf. Demirdache \& UribeEtxebarria, 2000, 2004; Mateu, 2002; Mateu and Amada-Simon, 1999; Smith, 1991; Stowell, 2007, among others). The implication follows that a verb in either of these forms will enter the Numeration with a [loc] feature (location understood here as temporal location) which will make it an adequate goal for [DI], that is, a potential intentional base. ${ }^{17}$

External Merge combines the lexical items in the Numeration to form a (conceptually legible) verbal projection hierarchically organized in terms of thematic prominence, with the external argument in the specifier of the light $\mathrm{v} * \mathrm{P}$ (as the most prominent thematically; cf. Bresnan and Kanerva, 1989; Carrier-Duncan, 1985; Fernández Soriano, 1999; Grimshaw, 1990; Koopman and Sportiche, 1991; Larson 1988; Levin and Rappaport, 1995 and Van Valin, 1993, among others). The structurally most prominent nominal or locative category in this verbal projection will be the intentional base, that is, the constituent that values the core intentional feature [DI].

VP then merges with $\mathrm{T}$ and $\mathrm{C}$; as argued, in Spanish $\mathrm{T}$ inherits both, formal and core intentional EFs from $\mathrm{C}$ (see (7)). $\mathrm{T}$ attracts the verb and establishes an Agree relation (with no further attraction) with the DP subject, that is, the DP bearing Case,

\footnotetext{
${ }^{17}$ The role of grammatical aspect in the derivation of Spanish sentences is crucial in many respects. It does not only condition the eventual placement of the subject in the syntactic structure (as the discussion below will show) but may also determine the eventual classification of a predicate as individual-level (IL) or stage level (SL), with the consequences that follow. Note that, as traditionally described, ILs denote permanent properties whereas SLs convey transient properties (cf. Arche, 2006 for a discussion of this distinction). The standard view of the difference between the two is that only the later have an extra (Davidsonian) argument which locates the property or event expressed by the predicate in space and time (cf. Carlson, 1977; Diesing, 1992; Kratzer, 1995; Milsark, 1974). More recent views advocate, though, that this lexical structure may be modified by some grammatical means when the predicate is selected for the Numeration (see Chierchia, 1995 and Manninnen, 2001, among others). Grammatical aspect is one of those means in Spanish, and the locative feature that perfective aspect adds converts an IL predicate into a SL predicate susceptible of being located in place/time (María supo qué hacer en esa situación. 'Mary knew what to do in that situation'; Juan fue feliz durante un par de años. 'John was happy for a couple of years').
} 
person and number features in its local (closest) c-c domain: in Spec, $\mathrm{v}^{*} \mathrm{P}$ in full argument structures (12a: structures with a transitive or unergative predicate), or in spec,VP when there is no (Nominative) external argument (12b: structures with an unaccusative predicate or with a predicate which has a dative or locative external argument): ${ }^{18}$

$$
\begin{aligned}
& \text { (12) a. [v*P } \left.\mathrm{DP}_{\text {Nominative/person/number }} \mathrm{V}^{*}\left[\mathrm{vP}(\mathrm{DP}) \mathrm{V}_{([\mathrm{loc}])} \ldots\right]\right] \\
& \text { b. [vP } \left.\mathrm{DP} \mathrm{Nominative/person/number} \mathrm{V}_{(\text {[loc] })} \ldots\right]
\end{aligned}
$$

Since valuation of the agreement features of $\mathrm{T}$ does not force internal merge of the DP subject in TP, the DP subject will only leave the VP space and be preverbal if it is the intentional base targeted as the goal for the core intentional feature [DI]. This is always the case when the subject is the external argument of the predicate, as this is the most prominent one structurally, the standard correlation between (morphological) subject, thematic subject and logical (or notional) subject following from this (cf. Erteschik, 1997; Keenan, 1976; Kiss, 1995; Kuroda, 1972; Reinhart, 1981 among others). Consequently, no thetic d-sentences will be possible with these predicates: ${ }^{19}$

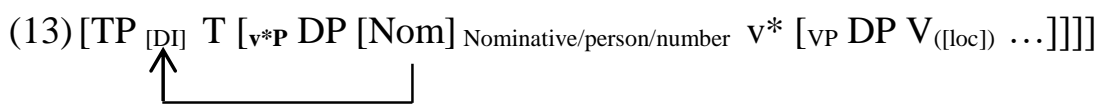

As argued, the intentional base must also be semantically prominent and represent an existing reference (i.e. be referential), something which rules out nominal constituents with an existential reading. In Spanish, bare NPs unmarkedly have this reading and this renders them inadequate to be intentional bases (and thus to value [DI])

18 On V-raising in Spanish see, among others, Ayaun (2005), Contreras (1991), Olarrea (1996), Ortega-Santos (2008), Suñer (1994), Torrego (1984) and Zubizarreta (1998). On agreement with the inflected DP subject in its underlying position (i.e. at a distance) see, among others, Breul (2004), Fernández Soriano (1999), López (2009), Villa-García (forthcoming) and Zubizarreta (1998).

19 As an anonymous reviewer notes, there are situations where sentences with transitive or unergative predicates can have a thetic reading. This always occurs, for example, when these sentences are preceded by the question What happens/happened?, which requires an all-focus (i.e. thetic) answer. Note, however, that a question such as What happens/happened? is context-setting and the point I make here only applies to d-sentences, that is, sentences which appear in isolation. As argued, the intentional status of d-sentences as categorical or thetic statements will solely depend on the type of category which values [DI], and this is determined by conditions of prominence. Sentences with transitive or unergative predicates will always have a categorical reading in this case because if some constituent different from the subject were targeted as the intentional base (i.e. as a goal for [DI]), the DP subject in Spec, $\mathrm{V}^{*} \mathrm{P}$ would cause an intervention problem. 
in d-sentences. Therefore, if the structurally most prominent argument is a bare NP a conflict arises and the derivation is not legible for the intentional-interface in $\mathrm{d}$ sentences. $^{20}$

(14)*Estudiantes no participaron en la manifestación

Students no participate-PRESENT.3PL in the demonstration

'Students did not participate in the demonstration'

Note however that, when coordinated or conveniently modified, bare NPs get a referential reading, and thus become potential intentional bases. Predictively, they will appear preverbally in d-sentences in these cases:

(15)a. Hombres y mujeres trabajaron toda la noche.

Men and women work-PAST.PERFECTIVE.3PL all the night

'Men and women worked all night.'

b. Personas de todas las edades le aplaudieron con entusiasmo.

People of all the ages him applaud-PAST.PERFECTIVE.3PL with enthusiasm 'People of all ages applauded him enthusiastically.'

When the external argument is a referential expression it will always be targeted as the intentional base and thus raises to TP to internally merge there, becoming the logical subject. In this position the DP establishes a relationship with the verb which, as expected, is interpretative in nature. For example, predicates with a bound, locative reading (i.e. in the perfective aspect) force specificity, thus allowing for definite (16a,b) or indefinite $(16 \mathrm{c}, \mathrm{d}) \mathrm{DP}$ subjects with this reading, but ruling out set-referring DPs $(16 \mathrm{e}):^{21}$

${ }^{20}$ This is a semantic restriction on intentional bases in d-sentences, not on preverbal subjects. In fact, the preverbal bare NP subject in (14) would be possible if it had been annotated as a contrastive topic in a particular context (see section 3.2):

(i) Estudiantes no participaron en la manifestación, pero sí profesores. [c]

Students no participate-PAST.3PL in the demonstration, but yes teachers

'Students did not participate in the demonstration, but teachers did.'

${ }^{21}$ I relied on descriptive grammars and on introspection to make up the examples in this paper. A posteriori, I sought confirmation of my grammatical judgements from ten monolingual native speakers of Castillian Spanish, all of them with higher-education qualification. I had an individual interview with each of my informants where I presented them with a number of examples and told them to answer just 


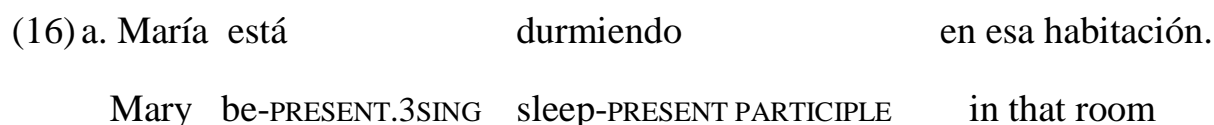

'Mary is sleeping in that room.'

b. Los representantes sindicales abandonaron la reunión.

The representatives union abandon-PAST.PERFECTIVE.3PL the meeting

'The union representatives abandoned the meeting.'

c. Un hombre con camisa azul nos recibió a la entrada.

A man with shirt blue us meet-PAST.PERFECTIVE.3SING at the entrance

'A man in a blue shirt met us at the entrance.'

d. Un diputado/Uno de los diputados colocó la primera piedra.

A deputy / One of the deputies lay-PAST.PERFECTIVE.3sing the first stone

'One of the deputies laid the foundation stone.'

e. *Un/El buen estudiante estudió a diario.

A/The good student study-PAST.PERFECTIVE.3sing at daily

'A good student studied daily.'

On the contrary, predicates with a generic reading (i.e. in the imperfective aspect) allow for both specific (17a) and non-specific (i.e. set-referring: 17b) DPs in Spec,TP,

one question: 'Do you think this is a possible sentence in Spanish?' If they answered 'Yes', with no further specification, I took it for a confirmation of the d-status of the sentence (i.e. an intentionally adequate sentence even if in isolation); if they answered 'It would depend on ...', followed by some particular context specification, I assumed that the sentence was understood to be context-dependent; and if they answered 'I do not think so', I marked the sentence as intentionally anomalous (\#).

I first checked their intuitions with transitive and unergative predicates, using examples (16a-c), with a preverbal subject, and their alternative version with a postverbal subject (e.g. María está durmiendo en esta habitación/Está durmiento María en esta habitación 'Mary is sleeping in that room'). They all answered 'Yes' when the subject was preverbal (16 a-c) and 'It would depend on...' when it was postverbal. Then, I tested the position of the subject with psychological and locative verbs, using examples (19) and (23) in the text and their alternative version with a preverbal subject (e.g. A Juan le preocupa tu salud./Tu salud le preocupa a Juan/ 'Your health worries John'). They all answered 'Yes' when the subject was postverbal ((19) and (23)) and 'It would depend on...' when it was preverbal. Finally, for unaccusative structures I used examples (29a), (31a), (32a), (34a) and (34b) to test preverbal subjects; they unanimously answered 'Yes' to the first three and signaled the last two as intentionally anomalous. As for postverbal subjects, I used, (29b), (31b), (32b), (35a) and (35b); the answer was, again unanimously, 'Yes' except for (32b) and (35b), marked as intentionally anomalous unless understood as interrogative. 
the generic reading of the intentional base matching the unbound view of the event time in these cases: $:^{22}$

(17)a. El profesor de historia siempre prepara sus clases concienzudamente.

The teacher of history always prepare-PRESENT.3SING his classes conscientiously

'The teacher of history always prepares his classes conscientiously.'

b. Un/El buen profesor siempre prepara sus clases concienzudamente.

A/The good teacher always prepare-PRESENT.3SING his classes conscientiously

'A good teacher always prepares his classes conscientiously.'

In the structures above, the DP subject is thematically an agent or an experiencer with some kind of control over the event, that is, it is the external argument of the verb and therefore the most prominent structurally. There are cases, though, where the verb has an external argument which is not the DP subject. This is the case of psych verbs such as gustar 'like', preocupar 'worry', and molestar 'bother' (19-21), whose external argument is a dative experiencer, and also of constructions like those in (22-24), where the external argument is a locative phrase which signals the place where the state or event originates. The DP subject is thematically the theme here (the target of emotion in the case of pschy-verbs) and thus projects in the VP; see Fernández Soriano (1999), Marín \& McNally (2011) and Fábregas et al. (2017), among others, for exhaustive descriptions of these constructions: ${ }^{23}$

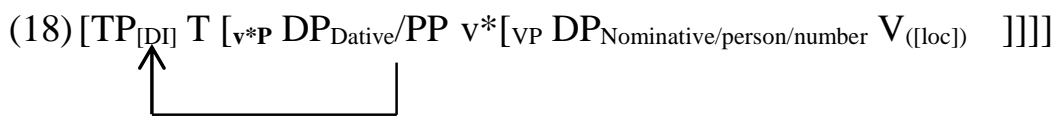

${ }^{22}$ Referential DPs can always value [DI] provided they match the interpretative restrictions of the predicate (as the contrast between (16e) and (17b) shows). Note in this respect that referentiality, specificity and definitenes should be not equated in Spanish (cf. Leonetti, 2016; Von Heusinger, 2002). Definite DPs are always referential and unmarkedly have specific reading (16a, 16b, 17a), though they can also be set-denoting (17b). In the same way, referential indefinite DPs unmarkedly have a setdenoting reading (17b) but can also be specific (a reading much aided with some modifier, as in $16 \mathrm{c}$, or with a partitive structure, as in $16 \mathrm{~d}$ )

23 To simplify, I use the seminal analysis in Belleti and Rizzi (1988) where these prepositional external arguments are projected in *vP. Alternative analyses with, for example, an Applicative Phrase in the case of dative experiencers (vid. Cuervo, 2003; Pylkkänen, 2002), or some extra verbal projection in the case of locative arguments (cf. Fernández Soriano, 1999) would make the same prediction since these projections always dominate the VP where the subject is located. 
As shown in (18), since the external argument is the intentional base targeted by TP to value [DI], the DP subject will necessarily remain postverbally in d-sentences in these cases: $:^{24}$

(19) A Juan le preocupa tu salud.

At John him worry-PRESENT.3SING your health

'Your health worries John.'

(20) A mi hermano le divierten mucho las fiestas de disfraces.

At my brother him entertain-PRESENT.3PL much the parties of costumes

'My brother enjoys costume parties a lot.'

(21) A mi hija le gusta el fútbol.

At my daughter her like-PRESENT.3SING the football

'My daughter likes football.'

(22) En esta habitación sobra una persona.

In this room excede-PRESENT.3SING one person

'There is one too many in this room.'

(23) Aquí falta el catálogo de la exposición.

Here lack-PRESENT.3SING the catalogue of the exhibition

'The exhibition catalogue is missing here.'

(24)En las carreteras locales ocurren muchos accidentes.

In the roads local occur-PRESENT.3PL many accidents

'Many accidents take place in local roads.'

As observed so far, the process of valuation of [DI] in d-sentences correctly predicts that the subject in Spanish will be preverbal when it is the external argument of the verb (transitive or unergative), but postverbal when some other category is the external argument. The possibilities opened are more varied in the case of unaccusative structures. The majority of unaccusatives denote existence (existir 'exist', quedar

${ }^{24}$ Examples (19) and (23) show that the postverbal DP subject can be definite and specific, which implies that no (in)definiteness/(non-)specificity effect is at stake here. (19)-(24) also show that the categorical/thetic interpretation of a d-sentence does not follow from the structural position of the subject in Spanish, but from the nominal or locative category of the constituent that values [DI]. Sentences (19)(21), with dative experiencers, are categorical statements even if the subject appears postverbally and sentences (22)-(24), where the external argument is a locative constituent, constitute thetic statements. 
'remain'...), appearance (aparecer 'appear', emerger 'emerge'...), change of state (externally caused: romper(se) 'break', abrir(se) 'open', hundir(se) 'sink', secar(se) 'dry'; or internally caused: florecer 'bloom', crecer 'grow', palidecer 'pale'...) or motion (llegar 'arrive', ir 'go', venir 'come'...). Assumedly, in these cases $\mathrm{v}^{*} \mathrm{P}$ does not project and therefore all the constituents in the VP are in the same minimal domain, which means that they are equally prominent and thus potential candidates as intentional bases (note that they are also structurally equidistant for the external attractor T; cf. Collins, 1997 and Rizzi and Shlonsky, 2006): ${ }^{25}$

$$
\text { (25) }\left[\mathrm { CP } \left[\mathrm{TP} \mathrm{T}_{[\mathrm{DI}]}\left[\mathbf{v P} \mathrm{DP}_{\text {Nominative/person/number }} \mathrm{V}_{([\mathrm{loc}])}\left(\mathrm{PP}_{[\text {[loc] }}\right)\right]\right.\right.
$$

In this configuration [DI] can attract a nominal or a locative constituent, including the verb when it enters the Numeration in the perfective or progressive aspect which, as assumed, adds a [loc] feature to its conceptual structure. Depending on which of the two options holds, the following possibilities obtain:

a) the DP subject is targeted by TP to value [DI], a categorical statement following; as in the case of transitive and unergative verbs, the intentional base must be referential in d-sentences, with grammatical aspect of the predicate determining its specific/setreferring reading (cf. the contrast between $26 \mathrm{~b}$ and $27 \mathrm{~b}$ ):

(26) a. El tren nocturno ha llegado/está llegando a la estación central.

The train nocturnal have-PRESENT.3SING arrive-PAST PARTICIPLE/be-PRESENT.3SING arrive-PRESENT PARTICIPLE at the station central

'The night train has arrived/is arriving at central station.'

b. \#Los trenes más modernos han llegado/están llegando a la estación central.

The trains more modern have-PRESENT.3PL arrive-PAST PARTICIPLE/be-PRESENT.3SING arrive-PRESENT PARTICIPLE at the station central

'The most modern trains have arrived at central station.'

(27)a. El tren nocturno llega a la estación central.

The train nocturnal arrive-PRESENT.3SING at the station central

25 On unaccusative verbs see, among others, Burzio (1986), De Miguel (1999), Mendikoetxea (1999), Levin and Rappaport (1995) and Perlmutter (1978). To simplify the exemplification, I will restrict myself here to examples with the verb llegar ('arrive'), a verb of inherently directed motion which shows all the semantic and syntactic properties of unaccusatives; I will also use the same elements in the Numeration, so that the contrasts in word-order can be more easily detected. 
'The night train arrives at central station.'

b. Los trenes más modernos llegan a la estación central.

The trains more modern arrive-PRESENT.3SING at the station central

'The most modern trains have arrived at central station.'

b) A locative category binding the event to a particular space or time is targeted by TP to value [DI], a thetic statement following. Note, in this respect, that a verb like llegar has a locative argument in its conceptual structure which expresses the achieved endpoint, i.e. the attained location (cf. Levin and Rappaport, 1995). As (25) shows, when the verb is in the perfective or progressive aspect $\left(\mathrm{V}_{[l o c]}\right)$, and the Numeration includes this locative phrase as well, the two constituents can potentially be the intentional base. The competition between the two is resolved, as predicted, on purely computational terms: since $\mathrm{V}_{[\text {loc] }}$ must be independently attracted to $\mathrm{T}$ to value the phifeatures there, its also being the intentional base results in a more economical derivation; therefore the verb raises to value [DI] and the subject remains postverbally:

(28)Ha llegado/Está llegando el tren nocturno a la estación central.

have-PRESENT.3SING arrive-PAST PARTICIPLE/be-PRESENT.3SING arrive-PRESENT PARTICIPLE the train nocturnal at the station central

'The night train has arrived/is arriving at central station.'

The analysis argued for here implies that examples (26a) and (28), repeated below for convenience in the perfective form, are both intentionally adequate as d-sentences and only differ in terms of which category serves to value the [DI] feature: ${ }^{26}$

(29)a. El tren nocturno ha llegado a la estación central.

${ }^{26}$ This double option is possible with the majority of unaccusative verbs in the perfective or the progressive aspect, not only with those which are semantically locative (as has been sometimes claimed; vid. the discussion in Ortega-Santos, 2008: 97ff):

(i) Juan ha muerto / Ha muerto Juan.

John have-PRESENT.3SING die-PAST PARTICIPLE / Have-PRESENT.3SING die-PAST PARTICIPLE John

'John has died.'

(ii) El rosal ha florecido / Ha florecido el rosal.

The rose bush have-PRESENT.3SING bloom-PAST PARTICIPLE / Have-PRESENT.3SING bloom-PAST PARTICIPLE the rose bush

'The rose bush has bloomed.' 
The train nocturnal have-PRESENT.3SING arrive-PAST PARTICIPLE at the station central

b. Ha llegado el tren nocturno a la estación central.

Have-PRESENT.3SING arrive-PAST PARTICIPLE the train nocturnal at the station central

'The night train has arrived at central station.'

This means that, contrary to what has been customarily proposed in the literature (cf. Arnaiz, 1998; Contreras, 1983; Fant, 1984; Gutiérrez-Bravo, 2007; Ortega-Santos, 2008), the canonical order in sentences with unaccusative verbs is not VS. In fact, both orders SV and VS (i.e. a categorical and a thetic statement) are possible when the verb is in the perfective aspect and, as expected, it is prominence, semantic this time, that favors one over the other. In particular, the DP tends to be targeted as the intentional base when it is ranked high in the referential hierarchy; assume for simplicity, a scale such as (30) (see Haude and Witzlack-Makarevich, 2016 for a discussion of the different referential hierarchies in the relevant literature): $:^{27}$

(30) Human > Specific (Definite > Indefinite) $>$ Set referring $>$ Existential

The more prominent a referent is in this scale, the more suitable it will be to mark the initialization of the event and therefore to be the intentional base. Consider in this respect the following options:

(31)a. \{Juan / El tren nocturno / Un tren muy viejo / \#Un tren \} ha llegado a la estación central.

\{John / The train nocturnal / A train very old / A train \} have-PRESENT.3sing arrive-PAST PARTICIPLE at the station central

' $\{$ John / The night train / A very old train / A train $\}$ has arrived at central station.'

b. Ha llegado \{Juan / el tren nocturno / un tren muy viejo / un tren\} a la estación central.

Have-PRESENT.3SING arrive-PAST PARTICIPLE $\{$ John / the train nocturnal / a train very old / a train $\}$ at the station central

' John / The night train / A very old train / A train $\}$ has arrived at central station.'

\footnotetext{
${ }^{27}$ Significantly, the semantic hierarchy in (30) may also serve to determine if a sentence is to be interpreted as categorical or thetic in English. For example, as Breul (2004:134, and references therein) notes, a human external argument favours a categorical reading, the unergative predicate thus receiving high pitch (represented in small capitals) in sentences like (i) but not in (ii) (vid. fn. 15):
}

(i) The EMPLOYEES PROTESTED.

(ii) The TRAIN whistled. 
All the native speakers consulted (vid. fn. 21) found the two sentences in (29) equally adequate to inaugurate the discourse (i.e. they did not need to make up a particular context to make them fit), but when asked for more detailed judgements, all of them preferred the categorical statement (31a) when the subject was specific and human, and most of them (seven out of ten) when it was specific and definite (Juan;El tren nocturno); on the contrary all of them preferred the thetic statement (31b) when the subject was specific but indefinite (Un tren muy viejo). They all agreed, however, that the opposite order could also be possible except in the case of Un tren (which they always placed postverbally), since here they activated the unmarked existential reading of the indefinite which would render it impossible as the intentional base.

The situation turns out to be different when the head of the verbal phrase is in the imperfective aspect, (29b) significantly contrasting with (32b) here:

(32)a. El tren nocturno llega a la estación central.

The train nocturnal arrive-PRESENT.3SING at the station central

b. \#Llega el tren nocturno a la estación central.

Arrive-PRESENT.3SING the train nocturnal at the station central

'The night train gets at central station.'

In (32a) the subject DP is targeted and raised to $\mathrm{TP}$, a categorical statement following. The anomaly of (32b) follows from the fact that the verb llega in the imperfective aspect has no [loc] feature and therefore cannot be a proper intentional base to value $[\mathrm{DI}]$. Note, however, that a thetic statement could be obtained if the locative argument of the verb were the intentional base: ${ }^{28}$

(33) A la estación central llega el tren nocturno.

At the station central arrive-PRESENT.3SING the train nocturnal

'The night train gets at central station.'

${ }^{28}$ Therefore, the so called locative inversion is not a unitary phenomenon in Spanish: it is an optional mechanism (i.e. associated with a particular discursive situation) when the unaccusative verb is in the perfective aspect, but the only possibility to obtain a d-sentence with a thetic interpretation when the verb is in the imperfective aspect (i.e. the sentence in (33) may well serve to inaugurate the discourse). 
Suppose now that the Numeration with a verb as llegar did not include any locative argument. Only the DP subject or the verb with a [loc] feature could in this case be targeted as the intentional base:

(34)a. \#\{Juan / El tren nocturno $\}$ ha llegado/está llegando.

\{John / The train nocturnal $\}$ have-PRESENT.3SING arrive-PAST PARTICIPLE/bePRESENT.3SING arrive-PRESENT PARTICIPLE

' $\{$ John / The night train $\}$ has arrived/is arriving.'

b. \#\{Juan / El tren nocturno $\} \quad$ llega.

\{John / The train nocturnal $\}$ arrive-PRESENT.3SING

' $\{$ John / The night train $\}$ arrives.'

(35) a. Ha llegado/está llegando \{Juan / el tren nocturno.

have-PRESENT.3SING arrive-PAST PARTICIPLE/be-PRESENT.3SING arrive-PRESENT PARTICIPLE $\{$ John / the train nocturnal $\}$

' $\{$ John / The night train $\}$ has arrived/is arriving.'

b. \#Llega $\quad\{$ Juan / el tren nocturno.

Arrive-PRESENT.3SING $\{$ John / the train nocturnal $\}$

' $\{$ John / The night train $\}$ arrives.'

None of the examples in (34) pose any problem for the valuation of the formal features of Case, number and person or for valuation of [DI], which means that it must be valuation of some other core intentional feature that determines their deviant status. As a matter of fact, they are ungrammatical because they lack a constituent to value the core intentional feature [IF] which marks the informational focus of the sentence: unaccusative verbs like llegar are inherently light and therefore cannot be the informational focus, contrary to what happens in the case of unergatives or unaccusatives of change of state (cf. the examples with preverbal subjects in fn. 26). Only if the Numeration included some additional constituent in VP would a categorical statement be possible in these cases: ${ }^{29}$

(36) a. $\{$ Juan / El tren nocturno $\}$ ha llegado/está llegando puntualmente.

${ }^{29}$ My informants unanimously found (34a) better than (34b) to inaugurate the discourse, but when asked to repeat the first of them, most introduced a temporal modifier in the structure, as ya; en este momento (i.e. they lexicalized the [loc] feature of perfective and progressive forms); obviously, this temporal modifier serves to value $[\mathrm{IF}]$ and makes the derivation intentionally adequate. 
\{John / The train nocturnal\} have-PRESENT.3SING arrive-PAST PARTICIPLE/bePRESENT.3SING arrive-PRESENT PARTICIPLE punctually

' $\{$ John / The night train $\}$ has arrived/is arriving punctually.'

b. $\{$ Juan / El tren nocturno $\}$ siempre llega puntualmente.

$\{$ John / The train nocturnal $\}$ always arrive-PRESENT.3SING punctually

' $\{$ John / The night train $\}$ always arrives punctually.'

As for the contrast in (35), it has to do with the different grammatical aspect of the verbal head in these cases. As argued, the only possibility to obtain a thetic statement in the absence of some locative phrase is by valuation of [DI] with a $\mathrm{V}_{[l o c]}$, that is, with a verb in the perfective or progressive aspect.

This means that a Numeration where the verb is of the llegar-type inflected for imperfective aspect and only the DP argument of that verb has been projected cannot lead to an intentionally legible object:

$$
\begin{aligned}
& \text { (37)a. \#Llega } \quad \text { Juan / el tren nocturno }\} . \\
& \text { Arrive-PRESENT.3SING }\{\text { John / the train nocturnal }\} \\
& \text { ' }\{\text { John / The night train }\} \text { arrives.' } \\
& \text { b. \#\{Juan / El tren nocturno }\} \text { llega. } \\
& \{\text { John / The train nocturnal }\} \text { arrive-PRESENT.3SING } \\
& \text { ' }\{\text { John / The night train }\} \text { train arrives.' }
\end{aligned}
$$

Note again that these sentences are structurally and semantically well formed, but impossible as d-sentences because they are not intentionally adequate. Only if the Numeration included the expletive form ahi ('there', unstressed, different from referential ahí; cf. Gutiérrez-Rexach, 2001) would it be convergent. Here I follow the convention in Gutiérrez-Rexach (2001) (from whom the existence of a set of weak adverbial clitic-like in Spanish has been taken) to write weak ahi without the graphic stress mark:

(38) Ahi llega $\quad\{$ Juan / el tren nocturno $\}$.

There arrive-PRESENT.3SING $\{$ John / the train nocturnal $\}$

'There arrives $\{$ John / The night train\}.'

Significantly, Dominican Spanish uses a nominal clitic ello ('it') instead of locative ahi in these contexts (vid. Toribio, 2000: 321), something which supports my claim that 
[DI] is an EPP feature in Spanish which must necessarily be valued in TP by a nominal or by locative category: ${ }^{30}$

(39) Ello llegan guaguas.

It arrive-PRESENT.PL buses

'There arrive buses.'

Finally note that the possibility to admit a weak adverbial as ahi ('there') in Spanish is not a distinctive property of unaccusatives (as sometimes proposed in the literature, cf. Bosque and Gutiérrez-Rexach, 2008; Gutiérrez-Rexach, 2001) but a property of unaccusatives when they enter the derivation in the imperfective aspect. Contrast, in this respect, (38) with (40):

(40)\#Ahi ha llegado/está llegando \{Juan / el tren nocturno\}.

There have-PRESENT.3SING arrive-PAST PARTICIPLE/be-PRESENT.3SING arrive-PRESENT PARTICIPLE $\{$ John / the train nocturnal $\}$

'There has arrived/is arriving \{John / The night train $\}$.'

If our proposal is on the right track, economy restrictions will exclude the weak adverbial from the derivation in (40) given that $\mathrm{V}_{[l o c]}$ is an adequate intentional base to value [DI] (cf. 35a). The role of core intentional features in the derivational process defended here therefore serves to explain an otherwise puzzling behaviour.

3.2. The position of the subject in Spanish context-sensitive sentences.

A theory of core intentional features gains its fundamental support from the effects these features have in d-sentences. As argued here, valuation of [DI] is regulated by the computational mechanism under conditions of structural and semantic prominence, and this explains the canonical position of the subject in these sentences. In the dynamics of language use, though, the intentional status of a proposition is necessarily connected to the part of the information state shared by the speaker and the hearer at a given point

\footnotetext{
${ }^{30}$ It has been argued that Spanish does not need to project Spec,TP since the EPP feature in this language can be satisfied by head movement of the verb (vid., among others, Alexiadou and Anagnostopoulou, 1998; Ordoñez and Treviño, 1999; Kempchinsky, 2002). Note, though, that this implies a conception of EPP in its original sense, that is, as the necessity to have a structural subject. The idea of [DI] as an EPP feature that I employ here (i.e. in the minimalist sense of an edge feature which forces movement) does not have the same implications since, as shown, [DI] can only be satisfied by the verbal head in some unaccusative structures.
} 
(the common ground, CG), which means that valuation of [DI] will necessarily be affected by the pragmatic structure of the sentence. Adopting Reinhart's (1981) wellknown metaphor, the common ground in a linguistic exchange may be understood as a set of file cards, and when the discourse referent of one of those cards is activated (i.e. it is labeled as topic) it is placed on top of the stack, so that the rest of the propositions can be stored under it. ${ }^{31}$ This implies that a constituent labeled as (some type of) topic may serve to value [DI], something which will in turn have effects in the final order of the constituents.

Recent analyses have shown that syntax and phonology crucially distinguish between three types of topics, hierarchically organized as follows (cf. Frascarelli and Hinterholzl (2007), Bianchi and Frascarelli (2010) and references therein):

\section{(41) Aboutness-shift Topic > Contrastive Topic > Familiar Topic}

As defined in Bianchi and Frascarelli, 2010, Aboutness-shift topics (A-topics) provide an instruction on how to update the propositional CG; they bring about a conversational move and must therefore be connected to clauses which realize a speech act implementing such conversational move (i.e. clauses with illocutionary force). Contrastive topics (C-topics) induce alternatives that create oppositional pairs with respect to other topics, that is, they provide an instruction to relate the asserted proposition(s) to a strategy of inquiry (cf. Kuno, 1976; Büring, 2003). Finally, Giventopics (G-topics, Familiar-topics in Frascarelli and Hinterholzl's (2007) analysis) are contextually entailed elements which do not affect the conversational dynamics. In terms of the contribution of these types of topics to the intentional reading of the sentence, a distinction shall then be made between A-topics and C-topics, which pertain to the dimension of what Krifka (2007) has termed CG management (i.e. the sequence of conversational moves that condition the development of the $\mathrm{CG}$ ), on the one hand,

\footnotetext{
${ }^{31}$ I will not address here the non-trivial question of how the pragmatic features for the different types of topics and foci are introduced the derivation of context-annotated sentences. It could be that in these sentences the lexical elements enter the Numeration endorsed with discourse features like [X-topic] or [X-focus], activated by previous contextual conditions. Alternatively, one could assume some distinctive level of structure at the interfaces (a post LF Assertion Structure as in Zubizarreta's (1998) analysis or a post-phasal Pragmatic Structure à la López, 2009). In any case, valuation of [DI] will be affected by the appearance of such features and, consequently, the position of the subject in the sentence will be affected as well.
} 
and G-topics, which relate to the dimension of CG content (i.e. the truth-conditional information accumulated up to a given point in the conversation), on the other.

With respect to the syntactic projection of the different topics, Frascarelli and Hinterholzl (2007) and Bianchi and Frascarelli (2010) propose a hierarchy in CP along the following lines:

(42) [ShiftP A-Topic [ContrP C-Topic [FocP [FamP* G-Topic [FinP [IP

On this view, all topics sit in non-argumental positions. In particular, A-Topics are realized in the highest TopP projection of the left periphery and G-Topics are located in the lowest TopP position (lower than focused elements); this implies that in multiple topic constructions G-Topics are always preceded by either A- or C-Topics.

There are many issues in the syntactic characterization of the different types of topics which are still far from clear, and one is precisely their actual location in the syntactic structure. ${ }^{32}$ I cannot pursue the issue in detail here but the properties described above clearly draw a line between A-/C-topics and G-topics in this respect. A-topics are connected to the illocutionary force of the clause and can be analysed as independent speech acts (cf. Krifka, 2001: 25), which supports the idea that they are projected in the $\mathrm{C}$-domain. There is empirical evidence in Spanish that C-topics must be placed in CP too; for example, the fact that they can be followed by the emphatic particle si (que) ('yes that') which arguably sits in one of the projections of the left periphery (cf. López, 2009; Batllori and Hernanz, 2013; Villa-García, 2016). Therefore, both A-topics and Ctopics must at some point be merged in (some projection of) $\mathrm{CP}$, where they can coexist.

G-Topics differ significantly from them, though. As mentioned above, both Atopics and C-topics pertain to the domain of CG management whereas G-topics don't; they just contribute to the CG content. Besides, as described in Frascarelli and Hinterhölzl (2007: 95), intonational contours illustrate that A-topics and C-topics are always marked by a final lowering, which typically signals the end of a prosodic phrase

\footnotetext{
32 See López (2009) and Rubio-Alcalá (2014) for an overview of the different proposals in this respect.
} 
with a declarative illocutionary force; G-topics, on the contrary, are not particularly signaled phonologically.

One way to capture the distinctive properties of G-topics is to assume that only these can value $[\mathrm{DI}]$ given that they update one file card already in the CG to make it the point of departure of the new proposition. Therefore when a category is signaled as [G-topic] it will be targeted by T, endowed with the feature [DI] in Spanish, and internally merged there. ${ }^{33}$ This explains why they are syntactically and prosodically different from $\mathrm{C}$ and A-topics, which sit in $\mathrm{CP} .{ }^{34}$

If this proposal is on the right track, the mechanism of valuation of [DI] proposed in (8) will have to be implemented as in (43) to include context-dependent sentences:

(43) Valuation of [DI]

a. In d-sentences, the category hosting [DI] probes a nominal or a locative constituent under conditions of semantic and structural prominence

b. In context-dependent sentences, the category hosting [DI] probes a nominal or a locative constituent annotated as a G-topic

The conditions in (43) imply that G-topics are intentionally equivalent to intentional bases in d-sentences, both serving the same purpose: to value the core-intentional feature [DI]. A G-topic therefore constitutes the starting point of the proposition in the relevant sense (i.e. it conveys an "aboutness" sense), and must then be subject to the

33 The prediction for an agreement-prominent language such as English (where, as argued, [DI] is accessed at PF) is that G-topics will be phonologically retrieved; this prediction seems to be borne out and no leftward topic structure is devoted to mere givenness marking in English (see Bianchi and Frascarelli, 2010: 27 for details).

34 Jiménez-Fernández y Migayawa (2014) place C-topics in TP. For them, whereas the topic feature for A-topics must remain at $\mathrm{C}$ regardless of the language type, the topic feature associated with $\mathrm{C}$ - and $\mathrm{G}$ topics may remain at $\mathrm{C}$ or be inherited by $\mathrm{T}$, depending on the type of language. In particular, they argue that in Spanish both are inherited by Tense, which in their analysis means that C-topics also undergo movement to Spec,TP, thus explaining why C-topicalization is not a root phenomenon in Spanish. As argued above, though, C-topics pattern both pragmatically and intonationally with A-topics, and they can even precede the complementizer que in Spanish (cf. Villa-García, 2015), something which strongly suggests that they do not sit in TP:

(i) Las patatas (sí que) las compré en esa tienda. [c]

The potatoes (yes that) them buy-PAST.3sing in that shop

'The potatoes I bought them in that shop.'

I will therefore continue to assume that only G-topics can value [DI] in TP and leave this peculiar behaviour of C-topics for further research. 
referentiality condition discussed above; given that G-topics retrieve information already present in the CG (i.e. is discourse-linked), they must also be semantically specific. $^{35}$

As argued above, the subject will be preverbal in a d-sentence when it is the most prominent argument in the verbal structure. In the case of context-dependent sentences, though, the subject will only be preverbal if it is annotated as G-topic, that is, its eventual position in the sentence will not be determined by its structural position in the VP but on its pragmatic prominence in the CG. Therefore, given an adequate context:

a) a structurally prominent subject will not be preverbal if some other constituent is labelled as a G-topic and internally merged in TP (compare (16a), (16c) and (16d) with (44)-(46)): ${ }^{36}$

$$
\begin{aligned}
& \text { (44) En esa habitación[G-topic] está durmiendo María. [c] } \\
& \text { In that room } \quad \text { be-PRESENT.3sING sleep-PRESENT PARTICIPLE Mary } \\
& \text { 'In that room Mary is sleeping.' }
\end{aligned}
$$

35 This sense of aboutness (and the referentiality/specificity requirement associated with it) also characterises, for obvious reasons, A-topics, which in my proposal do not value [DI] but target $\mathrm{CP}$ directly. An anonymous reviewer suggests that the equivalence between A-topics and G-topics in this respect could be preserved assuming that A-topics undergo movement to Spec,CP via Spec,TP, thus satisfying [DI] in the former category and the [top] feature in the latter. Conceptually attractive though it is, this solution will predict - contrary to fact, as example (52) shows- that A-topics and G-topics cannot coexist in the preverbal position in Spanish (i.e. they would compete for the same category), unless one admits a multiple specifier approach to TP. Given the implications of such a move, I leave for further research this particular issue and the more general question of the interaction between core intentional features and pragmatic features in Spanish.

${ }^{36}$ D-sentences (16a), (16c) and (16d) are repeated here for convenience:

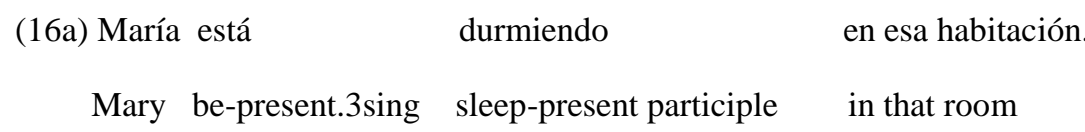

'Mary is sleeping in that room.'

(16c) Un hombre con camisa azul nos recibió a la entrada.

A man with shirt blue us meet-past.perfective.3sing at the entrance

'A man in a blue shirt met us at the entrance.'

(16d) Uno de los diputados colocó la primera piedra.

One of the deputies lay-past.perfective.3sing the first stone

'One of the deputies laid the foundation stone.' 
(45) A la entrada[G-topic] nos recibió

un hombre con camisa azul. [c]

At the entrance us meet-PAST.PERFECTIVE.3SING a man with shirt blue

'At the entrance, a man in a blue shirt met us.'

(46)La primera piedra[G-topic] la colocó uno de los diputados. [c]

The first stone it lay-PAST.PERFECTIVE.3SING one of the deputies

'The foundation was laid by one of the deputies.'

b) a subject structurally non-prominent will be preverbal if it is labelled as a G-topic and internally merged in TP (compare (19) and (24) with (47) and (48)): ${ }^{37}$

(47) $T$ u salud[G-topic] (le) preocupa mucho a Juan. [c]

Your health (him) worry-PRESENT.3SING much at John

'Your health worries John.'

(48) El accidente que te digo[G-topic] ocurrió en esta autopista. [c]

The accident that you tell-PRESENT.1SING occur-PAST.3SING in that highway

'The accident I am telling you about took place in that highway.'

Note in passing that, as contextually entailed, subject G-topics will normally be encoded by the covert pronominal pro, which means that this category can value [DI] in Spanish: ${ }^{38}$

(49) [Creo que a Juan le preocupa tu saludi $]$ Sí, pro $_{i}$ le preocupa mucho.

[I reckon that at John worry-PRESENT.3SING your health $\left.{ }_{\mathrm{i}}\right]$ Yes pro $_{\mathrm{i}}$ him worryPRESENT.3SING much

[I reckon that your health worries John]. 'Yes, it worries him a lot'

${ }^{37}$ D-sentences (19) and (24) are repeated here for convenience:

(19) A Juan le preocupa tu salud.

At John him worry-present.3sing your health

'Your health worries John.'

(24) En las carreteras locales ocurren muchos accidents.

In the roads local occur-present.3pl many accidents

'Many accidents take place in local roads.'

${ }^{38}$ I represent in brackets some previous utterance in the communicative exchange which could provide an antecedent for pro. See Jiménez-Fernández (2016) for a discussion of the discourse interpretation of null subject. 
(50) [Ese fue el peor accidente que vi en mi vida ${ }_{\mathrm{i}}$ ] Y pro ${ }_{i}$ ocurrió precisamente en esta autopista

[That was the worst accident that Horv]. And proi occur-PAST.3SING precisely in this highway

[That was the worst accident that I had ever seen] 'And it precisely took place in this highway'

Finally, c) the subject can also be an A-topic or a C-topic in Spec,CP, something that widens its distributional possibilities in context-dependent sentences: ${ }^{39}$

(51) Estudiantes[C-topic] sí vinieron, pero no profesores

Students yes come-PAST.3PL, but not professors

'Students came, but professors did not'

(52) (En cuanto a) Juan[A-topic], esa asignatura[G-topic] la suspendió tres veces

(As regards) John, that subject it fail-PAST.SING three times

'(As regards) John, that subject he failed it three times'

To summarize, the position of the subject in Spanish is crucially conditioned by the core intentional feature [DI] inherited by Tense in this language. In d-sentences this feature is valued by the subject or by some other nominal or locative constituent under conditions of grammatical prominence, whereas in context-dependent sentences it is valued by the subject or by any other nominal or locative constituent annotated as a Gtopic.

The proposal I sustain here contributes to the longstanding debate about the position of the subject in Spanish and offers a new perspective in which the SV/VS order can be predicted even in context-less sentences. In the relevant literature, authors like Burga (2009), Goodall (2002), Gupton (2010), López (2009), Ortega-Santos (2008) and Suñer (2003), among others, have claimed that preverbal subjects in Spanish systematically sit in TP, the category that standardly holds the structural subject crosslinguistically. On the contrary, other researchers such as Alexiadou and Anagnostopoulou, 1998; Barbosa,

\footnotetext{
${ }^{39}$ It has been widely assumed that topics show specificity effects and that, therefore, indefinites are excluded from topic positions (cf. Dalrymple and Nikolaeva, 2011; Endriss, 2009; Erteschik-Shir, 1997, 2013; Gundel and Fretheim, 2005; Reinhart, 1981, among others). Example (51) shows that this is not true (i.e. no particular set of students is presumed in these cases), at least in the case of contrastive topics (cf. Leonetti, 2016 who also notes the particular status of C-topics in this respect).
} 
2009; Contreras, 1991; Olarrea, 1996; Ordóñez, 1997; Ordóñez and Treviño, 1999, among others, argue that the interpretative properties of preverbal subjects can only result from their placement in a non-argumental position within the CP-layer. In my analysis, preverbal subjects in Spanish, except when A- or C-Topics, sit in TP, and they do because they need to value an intentional feature there. ${ }^{40}$ This means that TP must be conceived as an A-bar position in Spanish, a view which has also been sustained by Cardinaletti (2004), Gallego (2007), Masullo (1992), Uribe-Etxebarria (1992) and Zubizarreta (1998), among others. My proposal differs from them, though, in that it severely restricts the type of constituents which internally merge in Spec,TP: the most prominent argument in the conceptual structure of the verbal predicate in d-sentences and G-topics in context-dependent sentences. My analysis also serves to provide a principled explanation of the role of the lexical properties of the verbal predicate both in word order and in the determination of the eventual reading of the sentence as a categorical or a thetic statement in Spanish.

\section{Concluding remarks}

In this paper I have argued that there is a set of informational features which are part of the inventory of UG and subject to parametric variation. These core intentional features are edge features that make the sentence a legible object at the intentional interface (i.e. discourse-legible), even if it is not inserted in a communicative situation. In particular, I have dealt with the core intentional feature [DI], which organizes the information structure so that the sentence gets a categorical or a thetic reading. I have defined the conditions of valuation of [DI] and then tested them in Spanish, showing how the position of the subject is here clearly dependent on this feature.

This proposal implies that information structure (in particular, core intentional features) must be treated as an integral part of grammar, a point also made by proponents of a discourse-based articulation of the sentence (cf. Breul, 2004; Erteschik-

\footnotetext{
${ }^{40}$ As I have argued, when the subject is an A-topic or a C-topic it does not sit in TP but in CP. My view coincides in this sense with that of Camacho (2006, 2013), Casielles-Suárez (2004), López (2009), Richards (2016) and Villa-García (2015), among others, who claim that preverbal subjects may be both, CP- or TP- related elements (see Villa-García, forthcoming, for discussion).
} 
Shir, 1997; Lambrecht, 1994, among others). Note, though, that positing some sort of focus structure, as they do, force lexical items to enter the Numeration annotated with features like topic and focus on a par with formal features, since this is the only way for the Inclusiveness Principle (i.e. the impossibility to add new features in the course of the syntactic computation; cf. Chomsky 1995) to be respected. On standard definitions of these notions -which pertain to performance and are essentially connected to a contextual partition of the information- this is clearly counter intuitive for d-sentences. I have thus proposed that pragmatic features should be restricted to context-dependent sentences, where they serve to annotate constituents in terms of their relative salience in the discourse, and where they interact with core intentional features in a perspicuous way. Defining a restrictive set of core intentional features, different from contextdependent pragmatic features, will therefore serve to preserve the programmatic distinction between grammatical and pragmatic competence -and between the cognitive module that operates with purely syntactic expressions and those cognitive systems that are concerned with aspects of language use- a desirable move if one wants to keep with the restrictive agenda of the Minimalist program.

\section{References}

Alexiadou, A., Anagnostopulou, E., .1998. Parameterizing AGR: Word Order, VMovement and EPP-Checking. Natural Language and Linguistic Theory 16, 491-539.

Âmbar M., 1999. Aspects of the syntax of focus in Portuguese. In Rebuschi G, Tuller L. (Eds.), The grammar of focus. John Benjamins, Amsterdam/Philadelphia, pp. 23-53.

Arche, M., 2006. Individuals in Time: Tense, Aspect and the Individual/Stage distinction. John Benjamins, Amsterdam/Philadelphia.

Arnaiz, A., 1998. On the overview of the main word order characteristics of Romance. In: Siewerska, A., Rijkhoff, J., Bakker, D. (Eds.), Constituent word order in the languages of Europe. Mouton de Gruyter, Berlin, pp. 47-73

Ayoun, D. 2005. Verb movement in Spanish: "Mixed Languages" and Bilingualism. In: Cohen, J., McAlister, K. T., Rolstad, K., MacSwa, J. (Eds.), Proceedings of the 4th 
International Symposium on Bilingualism. Cascadilla Press, Somerville, MA, pp. 143162.

Barbosa P., 2001. On inversion in wh-questions in Romance. I: Hulk A, Pollock J-Y. (Eds.). Romance inversion. Oxford University Press, Oxford/New York, pp. 2-59.

Barbosa, P., 2009. Two Kinds of Subject pro. Studia Linguistica 63(1), 2-58.

Batllori, M., Hernanz, M. L., 2013. Emphatic polarity particles in Spanish and Catalan. Lingua 128, 9-30

Belleti, A., Rizzi, L., 1988. Psych-verbs and theta theory. Natural Language \& Linguistic Theory 6: 291-352.

Bianchi, V., Frascarelli, M., 2010. Is Topic a root phenomenon? Iberia 2(1), 43-88.

Bobaljik, J., Wurmbrand, S. 2005. The domain of agreement. Natural Language and Linguistic Theory 23, 809-865.

Bošković, Ž., 2016. Getting really edgy: On the edge of the edge. Linguistic Inquiry 47, 133.

Bosque I, 1980. Sobre la Negación. Cátedra, Madrid.

Bosque, I., Gutiérrez-Rexach, J., 2008. Fundamentos de Sintaxis Formal. Akal, Madrid.

Bresnan, J., Kanerva, J., 1989. Locative Inversion in Chichewa: A Case Study of Factorization in Grammar. Linguistic Inquiry 20: 1-50.

Breul, C., 2004. Focus Structure in Generative Grammar. An integrated syntactic, semantic and intonational approach. John Benjamins, Amsterdam/Philadelphia.

Burga, A. 2009. Spanish Subjects. PhD Dissertation, University of Illinois.

Büring, D., 1999. Topic. In: Bosch, P., van der Sandt, R. (Eds.), Focus: Linguistic, Cognitive, and Computational Perspectives. Cambridge University Press, Cambridge, pp. 142-165

Büring, D., 2003. On D-trees, beans, and B-Accents. Linguistics and Philosophy 26, 511545 . 
Burzio, L., 1986. Italian Syntax. Reidel, Dordrecht.

Camacho, J., 2006. Do Subjects have a Place in Spanish? In: Montreuil, J-P., Nishida, C. (Eds.), New Perspectives in Romance Linguistics. John Benjamins, Amsterdam/Philadelphia, pp. 51-66.

Camacho, J., 2013. Null Subjects. Cambridge University Press, Cambridge.

Carlson, G., 1977. Reference to Kinds in English, PhD. Dissertation, UMass Amherst.

Carrier-Duncan, J., 1985. Linking of Thematic Roles in Derivational Word Formation. Linguistic Inquiry 16: 1-34.

Cardinaletti, A., 2004. Toward a cartography of subject positions. In: Rizzi, L. (Ed.), The Structure of CP and IP, The Cartography of Syntactic Structures, Vol. 2. Oxford University Press, Oxford, pp. 115-165.

Casielles-Suárez, E., 2004. The Syntax-Information Structure Interface: Evidence from Spanish and English. Routledge, New York

Chierchia, G., 1995. Individual level predicates as inherent generics. In: Carlson, G., Pelletier, F. J. (Eds.), The Generic Book. The University of Chicago Press, Chicago, pp. 175-223.

Chomsky, N., 1995. The Minimalist Program. MIT Press, Cambridge, MA.

Chomsky, N., 2000. Minimalist Inquiries: The Framework. In Martin, R., Michaels, D., Uriagereka, J. (Eds.), Step by Step. Essays on Minimalist Syntax in Honour of Howard Lasnik. MIT Press, Cambridge, MA, pp. 89-155.

Chomsky, N., 2008. On phases. In: Freidin, R., Otero, C. P., Zubizarreta, M. L. (Eds.), Foundational Issues in Linguistic Theory. Essays in Honor of Jean-Roger Vergnaud. MIT Press, Cambridge, MA, pp. 133-166.

Cinque, G., 1990. Types of $\bar{A}$-Dependencies. MIT Press, Cambridge, MA.

Collins, C. 1997. Local Economy. MIT Press, Cambridge, MA.

Comrie, B., 1976. Aspect. Cambridge University Press, Cambridge. 
Contreras, H., 1991. On the position of subjects. In: Rothstein, S. (Ed.), Syntax and Semantics: Perspectives on phrase structure: heads and licensing, Vol 25. Academic Press, New York, pp. . 63-79.

Contreras, H., 1983. El orden de palabras en español. Cátedra, Madrid.

Cruschina, S., 2012. Discourse-related features and functional projections. Oxford University Press, Oxford/New York.

Cuervo, M. C., 2003. Datives at large. PhD, MIT.

De Miguel, E., 1999. El aspecto léxico. . In: Bosque, I., Demonte, V. (Eds.), Gramática Descriptiva de la Lengua Española, RAE Espasa, Madrid, pp. 2977-3060.

Demirdache, H., Uribe-Etxebarria, M., 2000. The primitives of temporal relations. In: Martin Roger, M., Michaels, D., Uriagereka, J. (Eds.), Step by step: Essays on minimalist syntax in honour of Howard Lasnik. MIT Press, Cambrdige, MA, pp. 157186.

Demirdache, H., Uribe-Etxebarria, M., 2004. The syntax of time adverbs. In: Guéron, J., Lecarme, J. The Syntax of Time, The MIT Press, Cambridge, MA. pp. 143-179

Diesing, M., 1992. Indefinites. MIT Press, Cambridge, MA.

Dalrymple, M., Nikolaeva, I., 2011. Objects and Information Structure. Cambridge University Press, Cambridge.

Endriss, C., 2009. Quantificational Topics. A Scopal Treatment of exceptional Wide Scope Phenomena. Springer, Dordrecht.

Erteschik-Shir, N., 1997. The Dynamics of Focus Structure. Cambridge University Press, Cambridge.

Erteschik-Shir, N., 2013. Information structure and (in)definiteness. In: Cabredo-Hofherr, P., Zribi-Hertz, A. (Eds.). Syntax and Semantics: Crosslinguistic Studies on Noun Phrase Structure and Reference, vol. 39. Brill, Leiden, pp. 23-50.

Fant, L., 1984. Estructura Informativa en Español: Estudio sintáctico y entonativo. Alqmvist and Wiksell: Stockholm 
Fábregas, A., Jiménez-Fernández, Á. L., Tubino, M., 2017. What's up with datives? In Lopes, R., Ornelas de Avelar, J., Lazzarino Cyrino, S. (Eds.), Romance Languages and Linguistic Theory 12. Selected papers from the 45th Linguistic Symposium on Romance Languages (LSRL), Campinas, Brazil, John Benjamins, Amsterdam, pp. 29-47.

Fernández Soriano, O., 1999. Two types of impersonal sentences in Spanish locative and dative subjects. Syntax 2.2, 101-140.

Frascarelli M., Hinterhölzl R., 2007. Types of topics in German and Italian. In: Schwabe $\mathrm{K}$, Winkler, S. (Eds.). On information structure, meaning and form. John Benjamins, Amsterdam/Philadelphia, pp. 87-116.

Gallego, Á. J., 2007. Phase theory and parametric variation. Ph.D. dissertation, Universitat Autònoma de Barcelona.

Goodall, G., 2002. On Preverbal Subjects in Spanish. In: Satterfield, T., Tortora, C., Cresti, D. (Eds.), Current Issues in Romance Languages: selected papers from the 29th Linguistic Symposium on Romance Languages (LSRL). John Benjamins, Amsterdam/Philadelphia, pp. 95-109.

Grimshaw, J., 1990. Argument Structure. Linguistic Inquiry Monograph 18, MIT Press, Cambridge, MA.

Gundel, J. K., 1999. Topic, Focus, and the Grammar-Pragmatics Interface. In: Alexander, J., Na-Rae, H., Fox, M. M. (Eds.), Proceedings of the 23rd Annual Penn Linguistics Colloqium. University of Pennsylvania Working Papers in Linguistics 6.1.

Gundel, J. Fretheim, T., 2005. Topic and Focus. In Horn, L., Ward, G (Eds.), The Handbook of Pragmatics. Blackwell, Wiley, pp. 175-196.

Gupton, T.M. 2010. The syntax-information structure interface: subjects and clausal word order in Galician. Ph.D. Dissertation. University of Iowa

Gutiérrez Bravo, R., 2007. Prominence scales and unmarked order in Spanish. Natural Language and Linguistic Theory 25, 235-271 
Gutiérrez-Rexach, J., 2001. Adverbial weak pronouns: derivation and interpretation. In Gutiérrez-Rexach, J., Silva-ViIlar, L. (Eds.), Current issues in Spanish syntax and semantics. Mouton De Gruyter, Berlin, pp. 143-174.

Haude K., Witzlack-Makarevich, A., 2016. Referential hierarchies and alignment: An overview. Linguistics 54(3), 433-441

Horvath, J., 2010. Discourse-features, syntactic displacement, and the status of contrast. Lingua 120, 1346-1369.

Jiménez-Fernández Á. L., Miyagawa S. 2014. A feature-inheritance approach to root phenomena and parametric variation. Lingua 145: 275-302

Jiménez-Fernández, Á. L., 2015. Towards a typology of focus: Subject position and microvariation at the discourse-syntax interface. Ampersand 2, 49-60

Jiménez-Fernández, Á. L., 2016. When discourse met null subjects. Borealis 5(2), 173 189.

Keenan, E. L., 1976. Towards a universal definition of Subject. In: Li, C (Ed.), Subject and Topic, Academic Press, New York, pp. 303-333.

Kempchinsky, P., 2002. Locative inversion, PP topicalization and the EPP. In: Satterfield, T., Tortora, C., Cresti, D. (Eds). Current Issues in Romance Languages. John Benjamins, Amsterdam/Philadelphia, pp. 145-159.

Kiss, K. È. (Ed) (1995) Discourse Configurational Languages. Oxford University Press, Oxford

Kiss, K. É., 1998. Identificational focus versus information focus. Language 74, 245-273.

Koopman, H., Sportiche, D., 1991. The position of subjects. Lingua 85, 211-258.

Kratzer, A., 1995. Stage-level and individual-level predicates. In: G. Carlson, G., Pelletier, F.J. (Eds.), The Generic Book, University of Chicago Press, Chicago, pp. 125-175.

Krifka, M., 2001. Quantifying into question acts. Natural Language Semantics 9, 1-40. 
Krifka, M., 2007. Basic Notions of Information Structure. In :Féry, C., Fanselow, G. \& Krifka, M. (Eds.), Working Papers of the SFB632, Interdisciplinary Studies on Information Structure (ISIS) 6. Universitätsverlag Potsdam, Potsdam, 13-56

Kuno, S., 1972. The categorical and the thetic judgement. Evidence from Japanese syntax. Foundations of Language 9, 153-185.

Kuno, S., 1976. Subject, Theme, and the Speaker's Empathy. A reexamination of relativization phenomena. In: Li, C (Ed.), Subject and Topic, Academic Press, New York, pp. 417-444.

Kuroda, Y., 1972. The categorical and the thetic judgment: Evidence from Japanese syntax. Foundations of Language 9, pp. 153-185.

Ladusaw, W., 2000. Thetic and Categorical, Stage and Individual, Weak and Strong. In: Horn, L., Yasuhiko, K. (Eds.), Negation and Polarity. Oxford University Press, Oxford/New York, pp 232-242.

Lambrecht, K., 1994. Information Structure and Sentence Form: Topic, Focus, and the Mental Representation of Discourse Referents. Cambridge University Press, Cambridge

Larson, R., 1988. On the Double Object Construction. Linguistic Inquiry 19, 335-391.

Leonetti, M. 2016. Definiteness effects: the interplay of information structure and pragmatics. In: Fischer, S., Kupisch, T., Rinke, E. (Eds.), Definiteness Effects: Bilingual, Typological and Diachronic Variation. Cambridge Scholars: Cambridge.

Leonetti M., Escandell V., 2009. Fronting and verum-focus in Spanish. In Dufter A., Jacob D., (Eds.). Focus and background in romance languages. John Benjamins, Amsterdam/Philadelphia, pp. 155-204

Levin, B., Rappaport Hovav, M., 1995 Unaccusativity: At the Syntax-Lexical Semantics Interface, Linguistic Inquiry Monograph 26, MIT Press, Cambridge, MA.

López, L., 2009. A derivational syntax for information structure. Oxford University Press, Oxford/New York

Manninen, S., 2001. A minimalist analysis of stage level and individual level predicates. The Department of English in Lund: Working Papers in English Linguistics 1, 1-18 
Marín, R., McNally, L., 2011. Inchoativity, change of state, and telicity: Evidence from Spanish reflexive psychological verbs. Natural Language and Linguistic Theory 29: 467-502.

Masullo, P. J. 1992. Quirky Datives in Spanish and the non-nominative subject parameter. MIT Working Papers in Linguistics 16: 82-103.

Mateu, J., Amadas-Simon, L., 1999. Extended argument structure: progressive as unacussative. Catalan Working Papers in Linguistics 7, 159-174

Mateu, J., 2002 Argument Structure: Relational Construal at the Syntax- Semantics Interface, PhD. Dissertation, Universitat Autònoma de Barcelona.

Mendikoetxea, A., 1999. Construcciones inacusativas y pasivas. In: Bosque, I., Demonte, V. (Eds.), Gramática Descriptiva de la Lengua Española, RAE Espasa, Madrid, pp. 1575-1629.

Meinunger, A., 2000. Syntactic aspects of topic and comment. John Benjamins, Amsterdam/Philadelphia.

Milsark, G., 1974. Existential sentences in English. PhD Dissertation, MIT.

Olarrea, A., 1996. Pre- and Postverbal Subject Position in Spanish: A Minimalist Account, $\mathrm{PhD}$ Dissertation, University of Washington

Ordóñez, F., 1997. Word Order and Clausal Structure of Spanish and Other Romance Languages. PhD Dissertation, CUNY.

Ordóñez, F., Treviño, E.. 1999. Left dislocated subjects and the pro-drop parameter: a case study of Spanish. Lingua 107, 39-68.

Ortega-Santos, I., 2008. Projecting Subjects in Spanish and English. PhD Dissertation, University of Maryland.

Ortega-Santos, I., 2016. Focus-related Operations at the Right Edge in Spanish, John Benjamins: Amsterdam/Philadelphia 
Perlmutter, D., 1978. Impersonal Passives and the Unaccusative Hypothesis. In: Proceedings of the Fourth Annual Meeting of the Berkeley Linguistics Society, Berkeley Linguistics Society, University of California, Berkeley, pp. 157-89

Pylkkänen, L., 2002. Introducing arguments. PhD, MIT.

Quer J., 2002. Edging quantifiers. On QP-fronting in Western Romance. In Beyssade C, Bok-Bennema R, Drijkoningen F, Monachesi P. (Eds.). Romance languages and linguistic theory [Current Issues in Linguistics 232], John Benjamins: Amsterdam/Philadelphia, pp. 253-70.

Richards, N., 2016. Contiguity Theory. MIT Press, Cambridge, MA.

Reinhart, T., 1981. Pragmatics and linguistics: an analysis of sentence topics. Philosophica 27, 53-94.

Rizzi, L., 1997. On the Fine Structure of the Left Periphery. In Belletti, A., Rizzi, L. (Eds.), Elements of Grammar, Kluwer, Dordrecht, pp. 281-337.

Rizzi, L., Shlonsky, U., 2006. Satisfying the Subject Criterion by a Non Subject: English Locative Inversion and Heavy NP Shift. In: Frascarelli, M. (Ed.), Phases of interpretation. Mouton de Gruyter, Berlin, pp. 341-361.

Rubio Alcalá, C., 2014. Syntactic constraints on topicalization phenomena. PhD Dissertation, Universitat Autònoma de Barcelona.

Sasse, H. J., 1987. The thetic/categorical distinction revisited. Linguistics 25, 511-580.

Smith, C. S., 1991. The parameter of aspect. Kluwer: Dordrecht.

Stowell, T., 2007. The syntactic expression of Tense. Lingua 117, 437-463.

Strawson, P. F., 1964. Identifying reference and truth-values. Theoria 30: 96-118. doi: 10.1111/j.1755-2567.1964.tb00404.x

Suñer, M., 1994. V-movement and the licensing of argumental wh-phrases in Spanish. Natural Language and Linguistic Theory 12, 335-372

Suñer, M., 2003. The lexical preverbal subject in a Romance Null Subject Language. Where art thou?. In Núñez-Cedeño, R., López, L., Cameron R. (Eds.), A Romance 
Perspective on Language Knowledge and Use. Selected Papers from the 31st Linguistic Symposium on Romance Languages(LSRL). John Benjamins, Amsterdam/Philadelphia, pp. $341-358$

Toribio, J., 2000. Setting parametric limits on dialectal variation in Spanish, Lingua 110, 315-341.

Torrego, E., 1984. On inversion in Spanish and some of its effects. Linguistic Inquiry 15, 103-129.

Uribe-Etxebarria, M. 1992. On the structural positions of the subject in Spanish, their nature and their consequences for quantification. In: Lakarra, J., Ortiz de Urbina, J. (Eds.), Syntactic Theory and Basque Syntax, Supplements of the ASJU (Anuario del Seminario de Filología Vasca Julio de Urquijo), San Sebastian, Donostia, pp. 447-491.

Van Valin, R. D., 1990 Semantic parameters of split transitivity. Language 66, 221-260

Vallduví, E., 1992 The Informational Component. Garland Press, New York.

Villa-García, J. 2015. The Syntax of Multiple-que Sentences in Spanish. Along the left periphery. Issues in Hispanic and Lusophone Linguistics Vol. 2. John Benjamins, Amsterdam/Philadelphia.

Villa-García, J., 2016. TP-ellipsis with a polarity particle in multiple-complementizer contexts in Spanish: on topical remnants and focal licensors. Borealis 5(2), 135-172.

Villa-García, J., forthcoming. Properties of the Extended Verb Phrase: Agreement, the Structure of INFL, and Subjects in Spanish. In Geeslin, K. (Ed.), The Cambridge Handbook of Spanish Linguistics, Cambridge University Press, Cambridge.

Von Heusinger, K., 2002. Specificity and Definiteness in Sentence and Discourse Structure. Journal of Semantics 19, 245-274.

Zubizarreta, M.L., 1998. Prosody, Focus, and Word Order. MIT Press, Cambridge, MA 